\title{
INTENSIFIKASI PEMUNGUTAN PAJAK AIR TANAH SEBAGAI UPAYA MENINGKATKAN PENDAPATAN ASLI DAERAH KOTA TOMOHON
}

\author{
Heine Glorina Panekenan ${ }^{1}$, Linda Lambey ${ }^{2}$, Sintje Rondonuwu ${ }^{3}$ \\ 1,2,3 Jurusan Akuntansi, Fakultas Ekonomi dan Bisnis, Universitas Sam Ratulangi, Jl. Kampus Bahu, Manado, \\ 95115, Indonesia \\ E-mail : gpanekenan.gp@gmail.com
}

\begin{abstract}
Intensifying the Ground Water Tax Collection is an effort in increasing and optimizing revenue by collecting the tax attentively, strictly, and deliberately. The implementation of intensifying the ground water tax collection in Tomohon City, especially at Local Financial Agency of Tomohon City, can be considered acceptable realizing the increases in the ground water tax income this year. This research method used in this thesis was descriptive method which is collecting the data from research outcome then analyzes it. Furthermore, a conclusion is drawn and the research type used was descriptive qualitative. The research findings showed that the process of intensifying the ground water tax collection at Local Financial Agency of Tomohon City is well implemented and according to applied regulation even though the goal set is not achieved, the revenue realization of ground water tax improved and therefore it becomes one of the locally-generated revenue of Tomohon City. Keywords : Ground-water tax, intensification, local tax, locally-generated revenue, efectiveness, efficiency.
\end{abstract}

\section{PENDAHULUAN}

Bangsa Indonesia telah mencanangkan suatu gerakan pembangunan yang dikenal dengan istilah pembangunan nasional. Dalam merealisasikan tujuan tersebut perlu diperhatikan masalah biaya pembangunan. Salah satu yang menjadi sumber dari dana pembiayaan pembangunan yang memakai masyarakat untuk berpartisipasi adalah pajak. Pajak merupakan kontribusi wajib dari masyarakat kepada negara yang bersifat terutang oleh pribadi atau badan yang bersifat memaksa berdasarkan Undang-undang, dengan tidak mendapatkan imbalan secara langsung dan digunakan untuk keperluan negara bagi sebesarbesarnya kemakmuran rakyat. Dalam meningkatkan penerimaan pajak yang memiliki peran penting adalah Pemerintah. Sumber pembiayaan terbesar yang ideal dalam penyelenggaraan pemerintahan daerah adalah Pendapatan Asli Daerah (PAD). Salah satu pos PAD dalam Anggaran Pendapatan dan Belanja Daerah (APBD) adalah pajak daerah.

Secara umum pajak daerah dibagi menjadi 2 bagian, yaitu: Pajak Provinsi dan Pajak Kabupaten/Kota. Pajak Provinsi yakni pajak yang dipungut oleh pemerintah pusat yang terdiri atas: Pajak atas Kendaraan Bermotor, Bea Balik Nama Kendaraan Bermotor, Pajak atas Bahan Bakar Kendaraan Bermotor, Pajak atas Air Permukaan, dan juga Pajak atas Rokok. Sedangkan Pajak Kabupaten/Kota, terdiri dari: Pajak Hotel, Pajak Restoran, Pajak Hiburan, Pajak Reklame, Pajak Penerangan Jalan, Pajak Mineral Bukan Logam dan Batuan, Pajak Parkir, Pajak yang dikenakan atasAir Tanah, Pajak yang dikenakan atas Sarang Burung Walet, ada juga Pajak Bumi dan Bangunan Perdesaan dan Perkotaan, dan Bea Perolehan Hak atas Tanah dan Bangunan.

Salah satu pajak yang digunakan dalam pembiayaan pembangunan nasional serta menjadi pendapatan asli daerah adalah pajak air tanah. Pajak air tanah diatur dalam UndangUndang Republik Indonesia Nomor 28 Tahun 2009 Tentang Pajak Daerah dan Retribusi Daerah. Pajak Air Tanah merupakan bagian dari Pajak Daerah maka dari itu pajak daerah 
merupakan pajak yang diatur dan dipungut berdasarkan peraturan daerah itu sendiri. Dalam penelitian ini penulis mengambil objek penelitian pada Badan Keuangan Kota Tomohon. Di Kota Tomohon, Peraturan tentang Pajak Daerah yang didalamnya membahas tentang Pajak Air Tanah diatur dalam Peraturan Daerah Kota Tomohon Nomor 7 Tahun 2012 Tentang Pajak Daerah. Dalam undang-undang tersebut dijelaskan bahwa Pajak Air Tanah adalah pajak dipungut atas kegiatan pengambilan dan/atau pemanfaatan air tanah.

Pajak Air tanah merupakan pajak yang cukup prospektif di masa mendatang. Dari waktu ke waktu pemanfaatan air tanah terus meningkat. Selain untuk keperluan rumah tangga masyarakat, air tanah juga dimanfaatkan oleh perusahaan untuk keperluan industri. Tumbuh pesatnya industri-industri dan perusahaan diikuti dengan meningkatnya kebutuhan akan penggunaan air tanah sebagai sumber air bersih untuk operasional usaha. Kota Tomohon merupakan kota yang memiliki penduduk yang cukup banyak, karena itu pemakaian sumber daya dalam hal ini penggunaan air bersih sangatlah dibutuhkan. Kota Tomohon juga memiliki pendatang-pendatang baik yang datang untuk menuntut ilmu sebagai siswa dan mahasiswa maupun yang datang karena ditugaskan untuk pekerjaan.

Kota Tomohon menjadikan Pajak Air Tanah sebagai salah satu sumber dari Pendapatan Asli Daerah (PAD). Peraturan Daerah Kota Tomohon Nomor 7 Tahun 2012 tentang Pajak Daerah bertujuan untuk meningkatkan realisasi penerimaan pajak daerah didalamnya adalah pajak air tanah dengan mengoptimalkan potensi yang ada di daerah tersebut. Berdasarkan Peraturan Daerah Kota Tomohon Nomor 7 tahun 2012 didalamnya pada Pasal 45 menyebutkan bahwa tarif pajak air tanah yang ditetapkan oleh pemerintah daerah adalah sebesar $15 \%$ (lima belas persen).

\section{TINJAUAN PUSTAKA}

\subsection{Konsep Akuntansi}

Ada beberapa definisi atau pengertian akuntansi yang berasal dari beberapa ahli yakni:

1. American Institute of Certified Public Accountants, menyatakan bahwa akuntansi adalah proses pencatatan, penggolongan, peringkasan, dan penyajian secara sistematis dari transaksi-transaksi keuangan suatu badan usaha, serta penafsiran terhadap hasilnya.

\subsection{Konsep Akuntansi Perpajakan}

Akuntansi perpajakan, secara prinsipil, terpengaruh oleh fungsi perpajakan itu karena ia merupakan implementasi ketentuan perpajakan. Selanjutnya, ketentuan itu merupakan perwujudan kebijakan perpajakan yang warnanya dipengaruhi oleh fungsi pajak. Karena fungsi utama pajak adalah penerimaan negara maka fungsi akuntansi pajak adalah melindungi hak penerimaan negara tersebut (public fiscal) (Gunadi, 2009:15).

\subsection{Konsep Pajak}

\subsubsection{Definisi dan unsur pajak}

Definisi pajak menurut Undang-Undang Nomor 16 tahun 2009 tentang perubahan keempat atas Undang-Undang Nomor 6 tahun 1983 yang memuat secara jelas dan terstruktur yang isinya memuat tentang Ketentuan Umum dan Tata Cara Perpajakan pada pasal 1 ayat 1 menuliskan "pajak merupakan sesuatu yang bersifat memaksa karena berdasar pada undangundang dan pajak merupakan kontribusi wajib dari masyarakat kepada negara yang terutang oleh orang pribadi atau badan digunakan untuk keperluan negara bagi sebesar-besarnya kemakmuran rakyat dengan wajib pajak tidak mendapatkan imbalan secara langsung".

Dari definisi tersebut, dapat disimpulkan bahwa pajak memiliki unsur-unsur:

1. Iuran dari rakyat kepada negara.

Yang berhak memungut pajak hanyalah negara. Iuran tersebut berupa uang (bukan barang).

2. Berdasarkan undang-undang. 
Pajak serta aturan pelaksanaannya dipungut oleh pemerintah dengan kekuatan atau berdasarkan undang-undang dan bersifat memaksa.

3. Tanpa jasa timbal atau kontraprestasi dari negara yang secara langsung dapat ditunjuk. Dalam pembayaran pajak yang dilakukan oleh masyarakat pemerintah tidak dapat menunjukkan adanya kontraprestasi individual oleh pemerintah.

4. Digunakan untuk membiayai segala pengeluaran rumah tangga negara, yakni pengeluaran-pengeluaran atau biaya-biaya penting yang bermanfaat bagi masyarakat luas.

\subsubsection{Pengelompokkan Pajak}

Menurut Mardiasmo (2016:7) pajak dikelompokkan dalam bagian, yakni:

1. Menurut golongannya

a. Pajak langsung, yaitu pajak yang harus ditanggung oleh Wajib Pajak dan tidak dapat dibebankan, dilimpahkan atau dibayarkan kepada orang lain.

Contoh: Pajak Penghasilan.

b. Pajak tidak langsung, yaitu pajak yang dapat dibebankan, dilimpahkan atau dibiayai oleh orang lain selain wajib pajak itu sendiri.

Contoh: Pajak Pertambahan Nilai.

2. Menurut sifatnya

a. Pajak Subjektif, yakni pajak yang berdasarkan pada subjeknya, maksudnya disini pemerintah memfokuskan dan memperhatikan keadaan dan situasi dari Wajib Pajak. Contoh: Pajak Penghasilan.

b. Pajak Objektif, yaitu pajak yang berpangkal pada objeknya, tanpa memerhatikan keadaan dari Wajib Pajak.

Contoh: Pajak Pertambahan Nilai dan Pajak Penjualan atas Barang Mewah.

3. Menurut lembaga pemungutnya

a. Pajak Pusat, yaitu pajak yang dipungut langsung oleh pemerintah pusat dan digunakan untuk membiayai pengeluaran negara atau biaya-biaya negara.

Contoh: Pajak Penghasilan, Pajak Pertambahan Nilai dan Pajak Penjuatan atau Barang Mewah, dan Bea Materai.

b. Pajak Daerah, yaitu pajak yang dipungut oleh Pemerintah Daerah dan bersifat memaksa karena berdasar pada undang-undang dan pajak tersebut akan digunakan untuk membiayai rumah tangga daerah.

Pajak Daerah terdiri atas:

1) Pajak Provinsi

2) Pajak Kabupaten/Kota

\subsubsection{Fungsi Pajak}

Menurut Mardiasmo (2016:4) ada 2 fungsi dari pajak, yaitu:

1. Fungsi anggaran (budgetair): Pajak berfungsi sebagai salah satu sumber dana bagi pemerintah untuk membiayai pengeluaran-pengeluarannya.

2. Fungsi mengatur (cregulerend): Pajak memiliki fungsi sebagai alat yang tentunya berguna untuk melaksanakan serta mengatur kebijaksanaan pemerintah dalam hal ini pada bidang sosial dan ekonomi.

\subsubsection{Syarat Pemungutan Pajak}

Menurut Mardiasmo (2016), syarat pemungutan pajak adalah sebagai berikut:

1. Pemungutan pajak harus adil (Syarat Keadilan)

2. Pemungutan pajak harus berdasarkan undang-undang (Syarat Yuridis)

3. Tidak menganggu perekonomian (Syarat Ekonomis)

4. Pemungutan pajak harus efisien (Syarat Finansiil)

5. Sistem pemungutan pajak harus sederhana 


\subsubsection{Sistem Pemungutan Pajak}

Sistem pemungutan pajak dibedakan menjadi tiga sistem, yaitu:

1. Self Assesment System: merupakan suatu sistem perpajakan yang memberikan kepercayaan penuh kepada Wajib Pajak dalam hal melaksanaan, memenuhi dan melaporkan sendiri kewajiban dan hak perpajakannya kepada pemerintah.

2. Official Assesment System: Suatu sistem perpajakan yang memposisikan fiskus sebagai pihak yang berinisiatif untuk memenuhi kewajiban perpajakan wajib pajak.

3. Withholding Tax System: Suatu sistem perpajakan yang menempatkan pihak tertentu (pihak ketiga) sebagai pihak yang mendapat tugas dan kepercayaan dari undangundang perpajakan untuk memotong atau memungut pajak terhadap suatu jumlah pembayaran atau transaksi yang dilakukan dengan wajib pajak.

\subsubsection{Tata Cara Pemungutan Pajak}

Tata cara pemungutan pajak dapat dilakukan sebagai berikut (Mardiasmo, 2016:8):

1. Stesel Pajak

Pemungutan pajak dapat dilakukan berdasarkan 3 stesel:

a. Stesel nyata (riel stesel)

b. Stelsel anggapan (fictieve stelsel)

c. Stelsel campuran

\subsection{Pajak Daerah}

\subsubsection{Definisi dan Dasar Hukum Pajak Daerah}

Menurut Mardiasmo (2016), Pajak daerah adalah kontribusi wajib kepada Daerah yang terutang dalam hal ini merupakan pribadi atau badan yang bersifat memaksa karena dilandaskan oleh Undang-undang, dengan tidak mendapatkan imbalan secara langsung dan digunakan untuk keperluan pengeluaran yang dilakukan oleh Daerah bagi sebesar-besarnya kemakmuran rakyat. Dasar hukum mengenai pemungutan Pajak Daerah dan Retribusi Daerah secara jelas tertuang dalam Undang-Undang No. 28 Tahun 2009 tentang menjelaskan secara jelas tentang Pajak Daerah dan Retribusi Daerah. Untuk Kota Tomohon, dasar hukum pemungutan pajak daerah dan retribusi daerah adalah Peraturan Daerah Kota Tomohon Nomor 7 Tahun 2012.

\subsubsection{Jenis Pajak dan Objek Pajak Daerah}

Menurut Undang-undang No. 28 Tahun 2009, Pajak Daerah dibagi menjadi 2 bagian, yaitu:

1. Pajak Provinsi, terdiri dari:

a. Pajak Kendaraan Bermotor

b. Bea Balik Nama Kendaraan Bermotor

c. Pajak Bahan Bakar Kendaraan Bermotor

d. Pajak Air Permukaan

e. Pajak Rokok

2. Pajak Kabupaten/Kota, terdiri dari:
a. Pajak Hotel
b. Pajak Restoran
c. Pajak Hiburan
d. Pajak Reklame
e. Pajak Penerangan Jalan
f. Pajak Mineral Bukan Logam dan Batuan
g. Pajak Parkir
h. Pajak Air Tanah
i. Pajak Sarang Burung Walet
j. Pajak Bumi dan Bangunan Pedesaan dan Perkotaan
k. Bea Perolehan Hak atas Tanah dan Bangunan 


\subsection{Pajak Air Tanah}

\subsubsection{Definisi Pajak Air Tanah}

Menurut Undang-undang Nomor 28 Tahun 2009, Bab 1 Pasal 1 ayat 33 tentang Pajak Daerah dan Retribusi Daerah, Pajak Air Tanah adalah pajak atas pengambilan dan/atau pemanfaatan air tanah. Air tanah adalah air yang terdapat dalam lapisan tanah atau batuan dibawah permukaan tanah.

\subsubsection{Dasar Hukum Pajak Air Tanah}

Berikut ini merupakan undang-undang yang memuat mengenai Pajak Daerah yang didalamnya terdapat Pajak Air Tanah:

1. Undang-Undang Nomor 28 Tahun 2009 tentang Pajak Daerah dan Retribusi Daerah.

2. Undang-Undang Nomor 22 Tahun 1999 tentang Pemerintah Daerah.

3. Undang-Undang Nomor 33 Tahun 2004 tentang Perimbangan Keuangan antara Pemerintah Pusat dan Pemerintah Daerah.

4. Peraturan Daerah Kota Tomohon Nomor 7 Tahun 2012 tentang Pajak Daerah.

\subsubsection{Tarif Pajak Air Tanah}

Berikut merupakan ketentuan mengenai tarif pajak air tanah berdasarkan Undang-undang No. 28 Tahun 2009, Bab II Pasal 70 tentang Pajak Daerah dan Retribusi Daerah:

1. Tarif Pajak Air Tanah yang tertulis adalah paling tinggi sebesar 20\% (dua puluh persen).

2. Tarif Pajak Air Tanah yang ada tersebut ditetapkan oleh peraturan Peraturan Daerah. Menurut Peraturan Daerah Kota Tomohon Nomor 7 Tahun 2012 tentang Pajak Daerah, Tarif Pajak Air Tanah yang diterapkan di Kota Tomohon adalah sebesar 15\% (lima belas persen). Dengan demikian, setiap daerah kabupaten/kota mendapat kewenangan atau hak untuk menetapkan tarif pajak yang harus dibayar oleh masyarakat yang mungkin berbeda dengan kota/kabupaten lainnya, asalkan tidak lebih melebihi tarif dalam undang-undang yakni sebesar $20 \%$.

\subsection{Pendapatan Asli Daerah}

Menurut Mardiasmo (2009:132), pendapatan asli daerah merupakan keseluruhan penerimaan yang diperoleh daerah dari sumber-sumber dalam wilayahnya sendiri yang dipungut berdasarkan peraturan daerah sesuai dengan peraturan perundang-undangan yang berlaku kemudian dipergunakan untuk menutupi segala pengeluaran daerah. Sedangkan pendapat dari Halim (2008:94), mengatakan bahwa Pendapatan Asli Daerah (PAD) adalah penerimaan pajak yang diperoleh daerah dari sumber-sumber dalam wilayahnya yang dipungut berdasarkan undang-undang dalam peraturan daerah dari sumber dalam wilayahnya yang dipungut dengan menjadikan peraturan daerah sebagai dasar sesuai dengan peraturan dalam undang-undang yang berlaku yang diantaranya meliputi penerimaan pajak daerah, penerimaan retribusi daerah, ada juga hasil perusahaan milik daerah, dan hasil pengelolaan kekayaan milik daerah yang dipisahkan dan yang terakhir lain-lain PAD yang sah.

\subsection{Intensifikasi Pajak}

Menurut Halim (2008:113) menyatakan bahwa Intensifikasi adalah suatu upaya, tindakan atau usaha-usaha untuk memperbesar penerimaan sehingga dapat tercapai atau terealisasinya target yang diinginkan atau anggaran yang telah ditetapkan dalam APBD sebelumnya dengan cara melakukan pemungutan yang lebih giat, ketat, dan juga teliti. Tunliu (2008) menyatakan pengertian dari intensifikasi pajak adalah suatu tindakan atau usaha-usaha yang dilakukan untuk memperbesar penerimaan pajak dengan cara melakukan pemungutan yang lebih giat, ketat, dan teliti dan lain-lain. 


\section{METODE PENELITIAN}

\subsection{Jenis Penelitian}

Jenis penelitian yang digunakan dalam penulisan skripsi ini adalah jenis penelitian deskriptif kualitatif. Menurut Sugiyono (2010:15), metode penelitian kualitatif menurutnya adalah metode penelitian yang memiliki landasan yakni filsafat positivise, yang dimaksud dengan filsafat positivise yakni digunakan untuk meneliti pada kondisi obyek yang alamiah (sebagai lawannya adalah eksperimen), pengambilan sampel sumber data yang ada dilakukan dengan cara purposive dan snowball, dimana peneliti bertindak instrument kunci. Teknik analisis data bersifat induktif/kualitatif pengumpulan data dilakukan dengan trianggulasi, dan hasil penelitian kualitatif lebih menekan makna dari pada generalisasi. Menurut Sujarweni (2014:11) penelitian deskriptif adalah penelitian sifatnya independen tanpa membuat hubungan maupun perbandingan dengan variabel yang lain.yang dilakukan untuk mengetahui nilai masing-masing variabel, baik satu atau lebih.

\subsection{Waktu dan Tempat Penelitian}

Penelitian pada penulisan ini mengambil tempat pada Badan Keuangan Daerah Kota Tomohon yang beralamat di Kolongan 2, Tomohon. Penelitian ini dilakukan di Pemerintah Kota Tomohon dengan mengambil data di Badan Keuangan Daerah Kota Tomohon. Penelitian ini dimulai pada bulan Maret 2018 dan berakhir pada bulan Mei 2018.

\subsection{Metode Analisis}

Metode analisis yang digunakan pada penelitian ini yakni:

1. Analisis Efektivitas

Efektivitas secara umum menunjukkan bahwa sampai seberapa jauh tercapainya suatu tujuan yang sebelumnya ditentukan terlebih dahulu. Efektivitas selalu terkait dengan hubungan antara hasil yang diharapkan dengan hasil yang sesungguhnya tercapai. Semakin besar hasil yang dicapai, maka semakin besar pula tingkat efektivitasnya dan sebaliknya (Nurmalasari, 2014).

$$
\text { Efektivitas }=\frac{\text { Realisasi dari total penerimaan Pajak Air Tanah }}{\text { Target dari total penerimaan Pajak Air Tanah }} \times 100 \%
$$

Tingkat efektivitas digolongkan ke dalam beberapa kategori sebagai berikut:

Tabel 2.1. Tingkat Efektivitas

\begin{tabular}{|c|c|}
\hline Rasio Efektivitas (100\%) & Kriteria \\
\hline$>100 \%$ & Sangat Efektif \\
\hline $90 \%-100 \%$ & Efektif \\
\hline $80 \%-90 \%$ & Cukup Efektif \\
\hline $60 \%-80 \%$ & Kurang Efektif \\
\hline$<60 \%$ & Tidak Efektif \\
\hline
\end{tabular}

2. Analisis Kontribusi

Kontribusi adalah keikutsertaan, keterlibatan, maupun sumbangan. Dengan demikian kontribusi dapat berupa materi atau tindakan. Kontribusi digunakan untuk mengetahui sejauh mana Pajak Air Tanah memberikan sumbangan dalam pendapatan asli daerah. kontribusi adalah sumbangan atau sesuatu kegiatan yang diberikan terhadap suatu kegiatan sehingga memberikan dampak yang bisa dirasakan (Fauziah, dkk. 2014).

$$
\text { Kontribusi }=\frac{\text { Realisasi Penerimaan Pajak Air Tanah }}{\text { Realisasi Penerimaan Pendapatan Asli Daerah }} \times 100 \%
$$


Tingkat kontribusi digolongkan ke dalam beberapa kategori sebagai berikut:

Tabel 2.2. Kriteria Kontribusi

\begin{tabular}{|c|c|}
\hline Kontribusi (100\%) & Kriteria \\
\hline$>50$ & Sangat Baik \\
\hline $40.10-50.00$ & Baik \\
\hline $30.10-40.00$ & Cukup Baik \\
\hline $20.10-30.00$ & Sedang \\
\hline $10.00-20.00$ & Kurang Baik \\
\hline$<10$ & Sangat Kurang \\
\hline
\end{tabular}

\section{HASIL ANALISIS DAN PEMBAHASAN}

4.1. Hasil analisis

4.1.1 Tingkat Perkembangan Penerimaan Pendapatan Asli Daerah Kota Tomohon

Tabel 4.1 Target dan Realisasi Pendapatan Asli Daerah

Badan Keuangan Daerah Kota Tomohon

Tahun 2013-2017

\begin{tabular}{|c|c|c|c|}
\hline Tahun & $\begin{array}{c}\text { Target } \\
\text { Pendapatan Asli Daerah (Rp) }\end{array}$ & $\begin{array}{c}\text { Realisasi } \\
\text { Pendapatan Asli Daerah (Rp) }\end{array}$ & $\begin{array}{c}\text { Presentase } \\
(\boldsymbol{\%})\end{array}$ \\
\hline 2013 & 12.700 .975 .000 & 13.945 .339 .275 & 109,80 \\
\hline 2014 & 21.206 .931 .368 & 17.378 .569 .341 & 81,95 \\
\hline 2015 & 25.039 .931 .368 & 20.688 .883 .680 & 82,62 \\
\hline 2016 & 26.383 .043 .368 & 26.011 .141 .966 & 98,59 \\
\hline 2017 & 31.526 .132 .000 & 29.543 .783 .344 & 93,71 \\
\hline
\end{tabular}

Sumber: Badan Keuangan Daerah Kota Tomohon

4.1.2 Target Dan Realisasi Pajak Air Tanah Tahun 2013-2017

Tabel 4.2 Target dan Realisasi Pajak Air Tanah

Badan Keuangan Daerah Kota Tomohon Tahun 2013-2017

\begin{tabular}{|c|c|c|}
\hline \multirow{2}{*}{ Tahun } & $\begin{array}{c}\text { Target } \\
\text { Pajak Air Tanah (Rp) }\end{array}$ & $\begin{array}{c}\text { Realisasi } \\
\text { Pajak Air Tanah (Rp) }\end{array}$ \\
\hline 2013 & 2.500 .000 & 943.125 \\
\hline 2014 & 1.000 .000 & 128.500 \\
\hline 2015 & 2.000 .000 & 2.065 .500 \\
\hline 2016 & 17.000 .000 & 1.130 .000 \\
\hline 2017 & 7.000 .000 & 2.945 .250 \\
\hline
\end{tabular}

Sumber: Badan Keuangan Daerah Kota Tomohon

\subsubsection{Efektivitas Penerimaan Pajak Air Tanah}

Tabel 4.3. Efektivitas Pajak Air Tanah Kota Tomohon

\begin{tabular}{|c|c|c|c|c|}
\hline Tahun & $\begin{array}{c}\text { Target } \\
\text { Pajak Air Tanah } \\
(\mathbf{R p})\end{array}$ & $\begin{array}{c}\text { Realisasi } \\
\text { Pajak Air Tanah } \\
(\mathbf{R p})\end{array}$ & $\begin{array}{c}\text { Efektivitas } \\
\mathbf{( \% )}\end{array}$ & Kriteria \\
\hline $\mathbf{( 1 )}$ & $\mathbf{( 2 )}$ & $\mathbf{( 3 )}$ & $\mathbf{( 4 )}=(\mathbf{3} \mathbf{~ 2 )} \mathbf{* 1 0 0 \%}$ & $\mathbf{( 5 )}$ \\
\hline 2013 & 2.500 .000 & 943.125 & 37,73 & Tidak Efektif \\
\hline 2014 & 1.000 .000 & 128.500 & 12,85 & Tidak Efektif \\
\hline 2015 & 2.000 .000 & 2.065 .500 & 103,28 & Sangat Efektif \\
\hline 2016 & 17.000 .000 & 1.130 .000 & 6,65 & Tidak Efektif \\
\hline 2017 & 7.000 .000 & 2.945 .250 & 42,08 & Tidak Efektif \\
\hline
\end{tabular}

Sumber: Data yang diolah 


\subsubsection{Kontribusi Pajak Air Tanah Terhadap Pendapatan Asli Daerah Kota Tomohon Tabel 4.4. Kontribusi Pajak Air Tanah Terhadap Pendapatan Asli Daerah Kota \\ Tomohon}

\begin{tabular}{|c|c|c|c|c|}
\hline Tahun & $\begin{array}{c}\text { Realisasi } \\
\text { Pajak } \\
\text { Air Tanah } \\
\text { (Rp.) }\end{array}$ & $\begin{array}{c}\text { Pendapatan Asli Daerah } \\
\text { (Rp.) }\end{array}$ & $\begin{array}{c}\text { Kontribusi } \\
(\%)\end{array}$ & Kriteria \\
\hline$(1)$ & $(2)$ & (3) & $(4)=(3: 2) * 100 \%$ & (5) \\
\hline 2013 & 943.125 & 13.945 .339 .275 & 0,0068 & Sangat Kurang \\
\hline 2014 & 128.500 & 17.378 .569 .341 & 0,0007 & Sangat Kurang \\
\hline 2015 & 2.065 .500 & 20.688 .883 .680 & 0,0100 & Sangat Kurang \\
\hline 2016 & 1.130 .000 & 26.011.141.966 & 0,0043 & Sangat Kurang \\
\hline 2017 & 2.945 .250 & 29.543 .783 .344 & 0,0100 & Sangat Kurang \\
\hline \multicolumn{3}{|c|}{ Rata-rata } & 0,0064 & Sangat Kurang \\
\hline
\end{tabular}

Sumber: Data yang diolah

\subsection{Pembahasan}

\subsubsection{Efektivitas Penerimaan Pajak Air Tanah Kota Tomohon}

Efektivitas Pajak Air Tanah pada tahun 2013 adalah sebesar 37,73\%, hal ini membuktikan bahwa Pajak Air Tanah tahun 2013 tidak efektif. Pada Tahun 2014 menunjukan tingkat efektivitas Pajak Air Tanah adalah sebesar 12,85\%, hal tersebut menunjukan efektivitas Pajak Air Tanah tidak efektif. Pada tahun 2015 menunjukan tingkat efektivitas Pajak Air Tanah adalah sebesar 103,28\%, hal tersebut menunjukan efektivitas Pajak Air Tanah sangat efektif. Pada tahun 2016 menunjukan tingkat efektivitas Pajak Air Tanah adalah sebesar 6,65\%, hal tersebut menunjukan efektivitas Pajak Air Tanah tidak efektif. Pada tahun 2017 menunjukan tingkat efektivitas Pajak Air Tanah adalah sebesar 42,08\%, hal tersebut menunjukan efektivitas Pajak Air Tanah tidak efektif. Jika dilihat dari jumlah rata-rata dari tahun 20132017 adalah sebesar 40,51\% yang menunjukkan bahwa tingkat efektivitas penerimaan Pajak Air Tanah dari tahun 2013-2017 adalah tidak efektif.

\subsubsection{Kontribusi Penerimaan Pajak Air Tanah Terhadap Pendapatan Asli Daerah Kota Tomohon}

Kontribusi Pajak Air Tanah terhadap Pendapatan Asli Daerah Kota Tomohon tahun 2013 adalah sebesar 0,0068\% dimana 99,9932\% disumbangkan oleh jenis pajak daerah yang lain, retribusi daerah, hasil pengelolaan kekayaan daerah yang dipisahkan, dan pendapatan asli daerah lain-lain yang sah. Hal ini menunjukan bahwa presentase kontribusi Pajak Air Tanah terhadap pendapatan asli daerah pada tahun 2013 adalah sangat kurang. Pada tahun 2014 adalah sebesar 0,0007\% dimana 99,9993\% disumbangkan oleh jenis pajak daerah yang lain, retribusi daerah, hasil pengelolaan kekayaan daerah yang dipisahkan, dan pendapatan asli daerah lain-lain yang sah. Hal ini menunjukan bahwa presentase kontribusi Pajak Air Tanah terhadap pendapatan asli daerah pada tahun 2014 adalah sangat kurang. Pada tahun 2015 adalah sebesar $0,001 \%$ dimana $99,999 \%$ disumbangkan oleh jenis pajak daerah yang lain, retribusi daerah, hasil pengelolaan kekayaan daerah yang dipisahkan, dan pendapatan asli daerah lain-lain yang sah. Hal ini menunjukan bahwa presentase kontribusi Pajak Air Tanah terhadap pendapatan asli daerah pada tahun 2015 adalah sangat kurang. Pada tahun 2016 adalah sebesar 0,0043\% dimana 99,957\% disumbangkan oleh jenis pajak daerah yang lain, retribusi daerah, hasil pengelolaan kekayaan daerah yang dipisahkan, dan pendapatan asli daerah lain-lain yang sah. Hal ini menunjukan bahwa presentase kontribusi Pajak Air Tanah terhadap pendapatan asli daerah pada tahun 2016 adalah sangat kurang. Pada tahun 2017 adalah sebesar $0,001 \%$ dimana $99,999 \%$ disumbangkan oleh jenis pajak daerah yang lain, 
retribusi daerah, hasil pengelolaan kekayaan daerah yang dipisahkan, dan pendapatan asli daerah lain-lain yang sah. Hal ini menunjukan bahwa presentase kontribusi Pajak Air Tanah terhadap pendapatan asli daerah pada tahun 2017 adalah sangat kurang. Pada tahun 20132017 rata-rata adalah sebesar 0,0064\% sehingga dapat disimpulkan bahwa kontribusi Pajak Air Tanah terhadap penerimaan Pendapatan Asli Daerah (PAD) Kota Tomohon adalah sangat kurang. Hal tersebut menunjukan bahwa pemerintah Kota Tomohon kurang serius dalam memperhatikan, memanfaatkan, dan mengoptimalkan sumber-sumber penerimaan yang tergolong dalam objek Pajak Air Tanah serta faktor-faktor lain yang mempengaruhi penerimaan Pajak Air Tanah. Namun, untuk tahun 2017 kontribusi Pajak Air Tanah merupakan kontribusi yang tertinggi sama halnya dengan tahun 2015. Hal tersebut menggambarkan bahwa Pemerintah Kota Tomohon sudah mulai menggali lebih dalam dalam penerimaan pajak air tanah dalam upaya untuk mengoptimalkannya.

\subsubsection{Intensifikasi Pajak Air Tanah}

\section{Penyuluhan}

Penyuluhan merupakan salah satu tugas aparatur pajak sesuai dengan dijelaskan dalam Undang-Undang Perpajakan. Berdasarkan Surat Edaran Direktorat Jenderal Pajak Nomor: SE-98/PJ/2011, Penyuluhan perpajakan dapat diartikan sebagai suatu upaya dan proses memberikan informasi perpajakan untuk menghasilkan perubahan pengetahuan, sikap masyarakat, dunia usaha, aparat, keterampilan, dan, serta lembaga pemerintah maupun non pemerintah agar terdorong untuk paham, sadar, berkontribusi dan peduli dalam melaksanakan kewajiban dalam bidang perpajakan. Pembinaan masyarakat dapat dilakukan melalui upayaupaya, diantaranya seperti penerangan langsung kepada masyarakat maupun pemberian penyuluhan pengetahuan perpajakan melalui media massa. Direktorat Jenderal Pajak (DJP) telah melakukan upaya penyuluhan pajak baik melalui media cetak maupun media elektronik bersama dengan Pemerintah Daerah. Sesuai dengan hasil wawancara dari beberapa informan menyatakan bahwa Badan Keuangan Daerah Kota Tomohon telah melakukan penyuluhan tentang pajak sebagai salah satu upaya intensifikasi.

2. Pelayanan

Salah satu upaya yang dilakukan Badan Keuangan Daerah Kota Tomohon dalam meningkatkan kepatuhan wajib pajak adalah dengan memberi pelayanan yang baik kepada masyarakat dalam hal ini wajib pajak. Upaya untuk meningkatkan kualitas pelayanan yang dilakukan oleh BKD Kota Tomohon ini sangat diharapkan dapat meningkatkan kepuasan wajib pajak sehingga dapat membuat kepatuhan masyarakat terhadap bidang perpajakan bertambah. Paradigma baru menempatkan bahwa wajib pajak (masyarakat) harus diutamakan agar dapat meningkatkan kinerja pelayanan publik maka dari itu aparat pemerintah dan pemerintah daerah sebagai abdi negara bertugas dalam hal tersebut.

\section{Pemeriksaan}

Tujuan dari pemeriksaan pajak adalah menguji lebih dalam mengenai pemenuhan kewajiban dan kepatuhan perpajakan Wajib Pajak dalam hal melaksanakan ketentuan peraturan perundang-undangan perpajakan berdasarkan peraturan yang berlaku. Menurut Suandi (2006:100), menyatakan bahwa Pemeriksaan pajak adalah untuk meningkatkan kepatuhan (tax compliance), melalui upaya-upaya penegakan hukum (law enforcement), sehingga dapat meningkatkan penerimaan pajak.

Menurut salah satu aparatur yang bertugas menjalankan penagihan dan pemeriksaan pajak menyatakan bahwa salah satu upaya optimalisasi penerimaan pajak air tanah yakni dengan melakukan pemeriksaan secara langsung.

4. Perhitungan Pajak

Kemampuan Wajib Pajak dalam hal menghitung besarnya kewajiban pajaknya yang harus dibayarkan akan sangat membantu aparat pajak dalam hal ini pemerintah dalam membantu memperlancar proses pemungutan pajak. Kemampuan Wajib Pajak dalam 
melakukan perhitungan kewajiban pajaknya sudah cukup baik. Dengan pemahaman yang lebih baik oleh Wajib Pajak, maka akan sangat membantu aparatur pajak dalam memperlancar proses pemungutan pajak. Selain itu, dengan pemahaman yang lebi hbaik tujuan pemungutan yang intensif akan tercapai karena wajib pajak akan menghitung sendiri seberapa besar kewajiban pajaknya sehingga kecil kemungkinan terjadinya pembebanan pajak yang tidak sesuai dengan penghasilan masyarakat Wajib Pajak.

5. Pendaftaran Wajib Pajak

Perkembangan jumlah wajib pajak terdaftar dapat dilihat dari Tabel dibawah ini:

Tabel 4.5

Perkembangan Jumlah Wajib Pajak Air Tanah Tahun 2013-2017

\begin{tabular}{|c|c|c|c|}
\hline Tahun & No & Wajib Pajak & Jumlah Wajib Pajak \\
\hline \multirow{4}{*}{2013} & 1 & Fides Sport & \multirow[t]{4}{*}{ 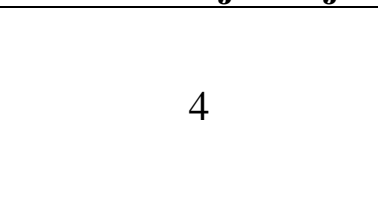 } \\
\hline & 2 & Car's Aquarius & \\
\hline & 3 & RS. Bethesda & \\
\hline & 4 & RS. Gunung Maria & \\
\hline \multirow{3}{*}{2014} & 1 & Fides Sport & \multirow{3}{*}{3} \\
\hline & 2 & RS. Bethesda & \\
\hline & 3 & RS. Gunung Maria & \\
\hline 2015 & 1 & Fides Sport & 1 \\
\hline \multirow{6}{*}{2016} & 1 & Fides Sport & \multirow{6}{*}{6} \\
\hline & 2 & Bless Auto Car & \\
\hline & 3 & Bali House & \\
\hline & 4 & Mountain View & \\
\hline & 5 & Jhoannie & \\
\hline & 6 & Green Garden & \\
\hline \multirow{9}{*}{2017} & 1 & Fides Sport & \multirow{9}{*}{9} \\
\hline & 2 & Aquarius (Walian) & \\
\hline & 3 & Aqua Sejuk & \\
\hline & 4 & Bless Auto Car & \\
\hline & 5 & Bali House & \\
\hline & 6 & Mountain View & \\
\hline & 7 & Jhoannie & \\
\hline & 8 & Green Garden & \\
\hline & 9 & Gardenia Hotel & \\
\hline
\end{tabular}

\section{Sumber: Badan Keuangan Daerah Kota Tomohon}

Jumlah wajib pajak terdaftar dapat kita lihat pada tabel 4.4 dimana pada tahun 2013 tercatat jumlah wajib pajak terdaftar yakni 4 wajib pajak mengalami penurunan pada tahun 2014 dan 2015, namun pada tahun 2016 meningkat secara signifikan menjadi 6 wajib pajak. Dan pada tahun 2017 kembali meningkat menjadi 9 wajib pajak. Dari data tersebut dan informasi dari beberapa informan dari Badan Keuangan Daerah Kota Tomohon kita dapat menyimpulkan bahwa tingkat kesadaran masyarakat untuk mendaftarkan dirinya sebagai Wajib Pajak dari tahun ke tahun semakin membaik khususnya untuk tahun ini namun belum optimal, hal ini membuktikan bahwa Sistem Pemungutan Pajak Air Tanah berjalan secara intensif akan tetapi semuanya tergantung pada kesadaran masyarakat dalam membayar pajak, mengingat potensi penerimaan pajak air tanah di Kota Tomohon cukup besar namun dikendalai oleh kesadaran masyarakat dalam melaporkan pajak. 


\section{A. Faktor Pendukung Intensifikasi \\ 1. Melakukan Penagihan Secara Langsung}

Proses penagihan pajak sangat berpengaruh dalam meningkatkan penerimaan pajak. Berdasarkan hasil wawancara penulis dengan salah satu aparatur pajak pada Badan Keuangan Daerah Kota Tomohon, beliau menerangkan bahwa sistem pemungutan pajak yang sementara dijalankan Badan Keuangan Daerah Kota Tomohon dalam memungut pajak air tanah ada 2 sistem yakni self assessment system dan official assessment system. Self assessment system merupakan sistem perpajakan yang memberikan hak penuh kepada Wajib Pajak untuk melaporkan dan melaksanakan sendiri apa yang menjadi kewajiban dan hak perpajakan mereka. Sedangkan, official assessment system merupakan suatu sistem perpajakan yang memposisikan fiskus sebagai pihak yang berinisiatif untuk memenuhi kewajiban perpajakan wajib pajak. Dari hal tersebut penulis menemukan bahwa pemerintah dalam hal ini Badan Keuangan Daerah melakukan penagihan secara langsung mengingat diterapkannya sistem pemungutan pajak yang memperankan pemerintah sebagai aparatur dalam memenuhi kewajiban wajib pajak.

\section{Reward and Punishment}

Minimnya jumlah wajib pajak air tanah, mengakibatkan sedikitnya jumlah penerimaan pajak air tanah. Namun, hal tersebut tidak lepas dari kesadaran masyarakat dalam membayar pajak. Dalam mendukung proses untuk mengoptimalkan pemungutan pajak air tanah, Badan Keuangan Daerah Kota Tomohon mengadakan Reward dan Punishment bagi para Wajib Pajak Air Tanah. Dari informasi tersebut dapat diketahui bahwa pemerintah mengadakan reward and punishment pada wajib pajak agar meningkatkan kesadaran wajib pajak dalam melaporkan dan membayar pajak. Reward merupakan bentuk penghargaan kepada wajib pajak yang taat membayar pajak, narasumber menyebutkan bahwa bentuk dari reward yang diberikan kepada wajib pajak adalah tanda terima kasih seperti sertifikat tertulis yang menyatakan wajib pajak taat dalam membayar pajak air tanah. Sedangkan punishment merupakan bentuk hukuman akibat dari wajib pajak yang tidak taat membayar pajak air tanah. Narasumber menyebutkan bentuk dari punishment terbagi atas beberapa tahap yakni teguran lisan, teguran tertulis, pencabutan izin, dan pada tingkat akhir dapat dikenakan pidana.

2. Peningkatan Skill Sumber Daya Manusia

Sumber Daya Manusia merupakan faktor yang penting dalam upaya pengoptimalan penerimaan pajak. Jumlah aparatur pajak yang bertugas dalam menangani penerimaan dan penagihan pajak mengambil peran yang sangat penting mengingat banyaknya jumlah wajib pajak yang belum melaporkan pajak mereka dalam hal ini wajib pajak air tanah. Oleh karena itu, peningkatan kualitas aparatur pajak juga memiliki peran yang penting. Berdasarkan hasil wawancara penulis dengan salah satu aparatur pajak pada Badan Keuangan Daerah Kota Tomohon penulis mendapatkan informasi bahwa para aparatur pajak mengikuti diklat dan bimbingan teknis yang diselenggarakan oleh pusat dalam rangka peningkatan kualitas sumber daya manusia dalam hal ini aparatur pajak dalam menangani penagihan dan penerimaan pajak.

\section{B. $\quad$ Faktor Penghambat Intensifikasi}

1. Kesadaran Masyarakat

Kesadaran wajib pajak dalam melaporkan dan membayar pajak memang masih sangat minim. Berdasarkan wawancara penulis, aparatur pajak mengatakan bahwa kurangnya kesadaran masyarakat merupakan faktor utama yang menghambat terlaksananya pemungutan pajak yang efektif. Warga negara Indonesia umumnya belum memiliki kesadaran untuk membayar pajak.

2. Regulasi 
Terbatasnya peraturan merupakan salah satu faktor yang menghambat proses intensifikasi. Peraturan yang ada harus sesuai dengan urutannya. Peraturan yang berada dibawahnya tidak bisa menabrak peraturan yang ada diatasnya sesuai dengan tata urutan perundang-undangan. Dalam hal ini penulis mendapat informasi dari wawancara yakni sebagai contoh PT Geothermal Energy. Dalam melakukan tugasnya melakukan pengeboran, mereka melakukan pengeboran ke arah dalam tanah dan otomatis yang pertama keluar dalam pengeboran tersebut adalah air tanah. Bisa dibayangkan banyaknya air tanah yang keluar akibat pengeboran tersebut. Dan itu dapat mengakibatkan terealisasinya penerimaan pajak air tanah dalam jumlah yang besar. Namun, hal tersebut tidak membuat PT Geothermal Energy terkena pajak air tanah karena terhambat regulasi. Undang-undang Perda Kota Tomohon tidak dapat melanggar undang-undang yang ada dari Provinsi oleh karena itu Pemerintah Daerah tidak memiliki kewenangan karena terbatasnya regulasi.

3. Kurangnya Sumber Daya Manusia

Sumber daya manusia merupakan salah satu faktor utama dalam terlaksananya pemungutan pajak dalam hal ini aparatur pajak. Berdasarkan hasil wawancara penulis dengan salah satu pegawai di bidang pajak dan retribusi pada Badan Keuangan Daerah Kota Tomohon menyatakan bahwa salah satu faktor yang menghambat terlaksananya pemungutan pajak air tanah yang efektif yakni kurangnya sumber daya manusia. Aparatur yang bertugas untuk menagih pajak cenderung sedikit dan belum mampu menjangkau wajib pajak air tanah secara keseluruhan.

4. Meter Air Belum Diterapkan Secara Keseluruhan

Perhitungan jumlah pajak yang akan dibayar pada wajib pajak air tanah dihitung melalui meter air sebagai alat ukur untuk mengetahui volume pengambilan air yang telah ditera oleh instansi yang berwenang. Volume air tanah yang digunakan wajib pajak untuk menentukan seberapa besar pajak air tanah yang terutang. Kenyataan dilapangan menunjukkan bahwa belum semua wajib pajak air tanah memiliki meter air, sehingga pemerintah mengalami kesulitan dalam penetapan pajak terutang. Berdasarkan hasil wawancara penulis, karyawan dari Badan Keuangan Daerah Kota Tomohon menyebutkan bahwa meter air merupakan salah satu faktor yang menghambat proses pemungutan pajak air tanah, namun pemerintah sedang dan sementara melaksanakan pembagian meter air secara menyeluruh untuk membantu proses pemungutan pajak air tanah.

\section{KESIMPULAN DAN SARAN \\ 5.1. Kesimpulan}

Tingkat efektivitas penerimaan pajak air tanah mendapat kriteria tidak efektif namun untuk tahun terakhir yakni tahun 2017 penerimaan pajak air tanah meningkat melebihi tahun-tahun sebelumnya itu berarti pemerintah dalam hal ini Badan Keuangan Daerah Kota Tomohon mulai berhasil menjalankan usaha dalam mengoptimalkan penerimaan pajak air tanah. Sedangkan kontribusi penerimaan pajak air tanah terhadap pendapatan asli daerah Kota Tomohon mendapat kriteria sangat kurang hal ini disebabkan oleh sedikitnya objek pajak pajak air tanah sehingga penerimaan pajak air tanah tergolong sedikit. Implementasi proses pemungutan pajak air tanah di Kota Tomohon secara praktek sudah dilaksanakan sesuai dengan pengertian pemungutan yang terdapat pada Undang-Undang Nomor 28 Tahun 2009, tetapi belum dilakukan secara menyeluruh sesuai dengan ketentuan perundang-undangan sehingga belum sepenuhnya optimal. Upaya yang dilakukan dalam intensifikasi penerimaan pajak air tanah merupakan salah satu pendapatan negara/daerah. Berikut merupakan intensifikasi pajak air tanah yang dilakukan Badan Keuangan Daerah Kota Tomohon:

a. Penyuluhan sudah berjalan dengan baik walaupun seringkali sudah tidak efektif karena mengingat media elektronik yang mampu menyebarkan informasi lebih jelas dan cepat kepada wajib pajak. 
b. Pelayanan sedang dioptimalkan oleh Badan Keuangan Daerah Kota Tomohon sebagai salah satu cara mengoptimalkan penerimaan pajak air tanah yakni dengan meningkatkan kualitas pemungut pajak (aparat pajak).

c. Pemeriksaan sedang dioptimalkan karena adanya wajib pajak yang belum melaporkan pajak mereka.

d. Pendaftaran Wajib Pajak. Pemungutan pajak dikatakan intensif jika tingkat kepatuhan Wajib Pajak semakin baik, untuk menciptakan hal tersebut satu indikator yang dapat membantu untuk meningkatan kepatuhan Wajib Pajak adalah semakin sadarnya masyarakat untuk mendaftarkan dirinya sebagai Wajib Pajak.

e. Perhitungan Pajak. Kemampuan Wajib Pajak agar dapat menghitung kewajiban pajaknya akan membantu aparat pajak dalam hal ini pemerintah dalam memperlancar proses pemungutan pajak.

Secara umum intensifikasi pemungutan pajak air tanah di Badan Keuangan Daerah Kota Tomohon sudah berjalan dengan baik, atau dengan kata lain intensifikasi pemungutan pajak air tanah sudah cukup efektif karena setiap tahunnya terjadi peningkatan penerimaan pajak oleh wajib pajak dan peningkatan jumlah wajib pajak. Karena peningkatan penerimaan pajak merupakan salah satu indikasi terjadinya peningkatan kesadaran wajib pajak.

Faktor-faktor yang membantu terlaksananya intensifikasi pajak yang baik yakni antara lain: proses pemungutan pajak secara langsung oleh aparat pajak, program Reward dan Punishment yang diadakan pemerintah, peningkatan skill sumber daya manusia (aparat pajak). Dalam melaksanakan intensifikasi pajak terdapat beberapa faktor-faktor yang menghambatnya antara lain: Kesadaran Masyarakat dalam membayar dan melaporkan pajak, terbatasnya regulasi, sumber daya manusia pemungut pajak yang masih kurang, dan penggunaan meter air yang belum diterapkan secara menyeluruh.

\subsection{Saran}

Untuk mengatasi jumlah wajib pajak yang masih sedikit dalam melaporkan dan membayar pajak, Badan Keuangan Daerah Kota Tomohon dapat mempertimbangkan untuk mengoptimalkan proses monitoring ke lapangan secara langsung dengan lebih teliti dan menyeluruh sehingga wajib pajak yang belum melaporkan pajak dapat bertambah tidak lalai dalam melaporkan pajak. Untuk mengatasi belum diterapkannya meter air secara keseluruhan terhadap wajib pajak, Badan Keuangan Daerah Kota Tomohon dapat mempertimbangkan untuk melakukan sosialisasi khusus kepada wajib pajak air tanah mengenai kewajiban pemasangan meter air di setiap titik pemanfaatan air tanah dengan cara penyuluhan maupun pendekatan langsung. Alternatif lain dalam menerapkan meter air yakni pemerintah dapat menyediakan dan membagikan meter air kepada wajib pajak yang memanfaatkan air tanah dan berkewajiban membayar pajak air tanah.

\section{DAFTAR PUSTAKA}

Gunadi. 2009. Akuntansi Pajak. Jakarta: Grasindo.

Mardiasmo. 2016. Perpajakan Edisi Terbaru 2016. Yogyakarta: ANDI

Republik Indonesia, 2009. Undang-Undang Nomor 16 Tahun 2009 Tentang Ketentuan Umum dan Tata Cata Perpajakan. Lembaran Negara RI Tahun 2009, No.16. Sekretariat Negara, Jakarta.

Republik Indonesia, 2009. Undang-Undang Nomor 28 Tahun 2009 Tentang Pajak Daerah Dan Retribusi Daerah. Lembaran Negara RI Tahun 2009, No. 28. Sekretariat Negara, Jakarta.

Sugiyono. 2010. Metode Penelitian Pendidikan Pendekatan Kuantitaitf, Kualitatif, Dan $R \& D$. Bandung: Alfabeta. 
Sujarweni, V. Wiratna. 2014. Metode Penelitian: Lengkap, Praktis, Dan Mudah Dipahami. Yogyakarta: Pustaka Baru Press.

Surat Edaran Direktorat Jenderal Pajak Nomor SE-98/PJ/2011 Tentang Pedoman Penyusunan Rencana Kerja dan Laporan Kegiatan Penyuluhan Perpajakan Unit Vertikal di Lingkungan Direktorat Jenderal Pajak.

Putra, Indra M.H. 2017. Pengantar Akuntansi. Yogyakarta: Quadrant.

Nurmalasari, Rany. 2014. Analisis Efektivitas Dan Kontribusi Proses Pelayanan Pengalihan Pengelolaan Serta Pemasukan Pajak Bumi Dan Bangunan Terhadap Pendapatan Daerah Kota Martaram. Malang: Universitas Brawijaya.

Peraturan Daerah Pemerintah Kota Tomohon, Nomor 7 Tahun 2012, Tentang Pajak Daerah.

Sugiyono. 2010. Metode Penelitian Pendidikan Pendekatan Kuantitatif, Kualitatif, Dan $R \& D$. Bandung: Alfabeta.

Sujarweni, V. Wiratna. 2014. Metode Penelitian: Lengkap, Praktis, Dan Mudah Dipahami. Yogyakarta: Pustaka Baru Press.

Surat Edaran Direktorat Jenderal Pajak Nomor SE-06/PJ.9/2001 Tentang Pelaksanaan Ekstensifikasi Wajib Pajak dan Intensifikasi Pajak. 